Article

\title{
How do the Employees's Perceptions of Abusive Supervision Affect Customer Satisfaction in the Chain Restaurants? Employee-Customer Level Analysis
}

\author{
Hyo Sun Jung ${ }^{1}$ and Hye Hyun Yoon ${ }^{2, *}$ \\ Center for Converging Humanities, KyungHee University, Seoul 02447, Korea; chefcook@khu.ac.kr \\ 2 Department of Culinary Arts and Food Service Management, KyungHee University, Seoul 02447, Korea \\ * Correspondence: hhyun@khu.ac.kr
}

Received: 1 July 2020; Accepted: 1 August 2020; Published: 3 August 2020

\begin{abstract}
The purpose of this study is to examine the effect of chain restaurant employees' perception of abusive supervision on employee satisfaction and customer satisfaction. The sample for the survey was collected from 228 customers and 93 employees in a chain restaurant. The results showed a negative relationship between abusive supervision and employee satisfaction. However, abusive supervision did not have a significant, direct effect on customer satisfaction, but showed an indirect effect via employee satisfaction. In addition, employee satisfaction was positively associated with customer satisfaction.
\end{abstract}

Keywords: abusive supervision; employee satisfaction; customer satisfaction; chain restaurants

\section{Introduction}

In recent years, destructive leadership and related issues have received growing attention, with research undertaken on the effects of abusive supervision, in particular. Research findings have suggested that a supervisor's abusive behavior in the workplace leads to employees' negative performance and incurs organizational costs [1,2]. Such behavior can be seen as abusive leadership, which Schyns and Schilling [3] defined as how the activities, experiences, and relationships of individuals or group members are repeatedly affected by a supervisor over a long period of time. The term abusive supervision [4] is most frequently referred to in relation to destructive leadership. Tepper [5] defined it as long-term abuse of subordinates through actions that include mockery, threats, intentional holding back of information, or silence. Many studies have cited abusive supervision as a principal cause of employees' chronic disability or stress [6-8]. Until now, researchers have paid most attention to positive leadership, focusing on a supervisor's dynamic roles in enhancing employees' work satisfaction $[9,10]$. The effect of bad leadership remains largely unknown. We therefore aimed to illuminate the dark side of leadership that negatively affects employee satisfaction and customer satisfaction. This study starts from the question of whether an abusive supervisor can make not only employees but also customers leave. There are many studies on work satisfaction and customer satisfaction, and yet little is known about the role of an abusive supervisor in triggering dissatisfaction.

Particularly in the foodservice industry, employees' attitudes and consequent service quality play a key role in creating a pleasant experience for customers and increasing their satisfaction; thus, internal marketing is of utmost importance to improve customer satisfaction [11,12]. Further, foodservice customers tend to be loyal to several restaurants at a time, and thus it is very important for restaurants to make good use of their human resources to ensure customer satisfaction and set their restaurants apart from others [13]. Many studies have been conducted to date on the effect of abusive supervision on employees' psychological well-being and work attitude [14-16]. No studies have been conducted on the 
effect of abusive supervision on customer satisfaction through the mediation of employee satisfaction because paired data between employees and customers are hard to collect, complicated, and costly. However, such a survey was conducted for this study, with the aim of assessing various suggestions made to date in the foodservice industry that have yet to be fully explored. We analyzed a path model that emphasized correlation between abusive supervision, employee satisfaction, and customer satisfaction, to test hypotheses that abusive supervision negatively affects employee satisfaction, which in turn reduces customer satisfaction (Figure 1).

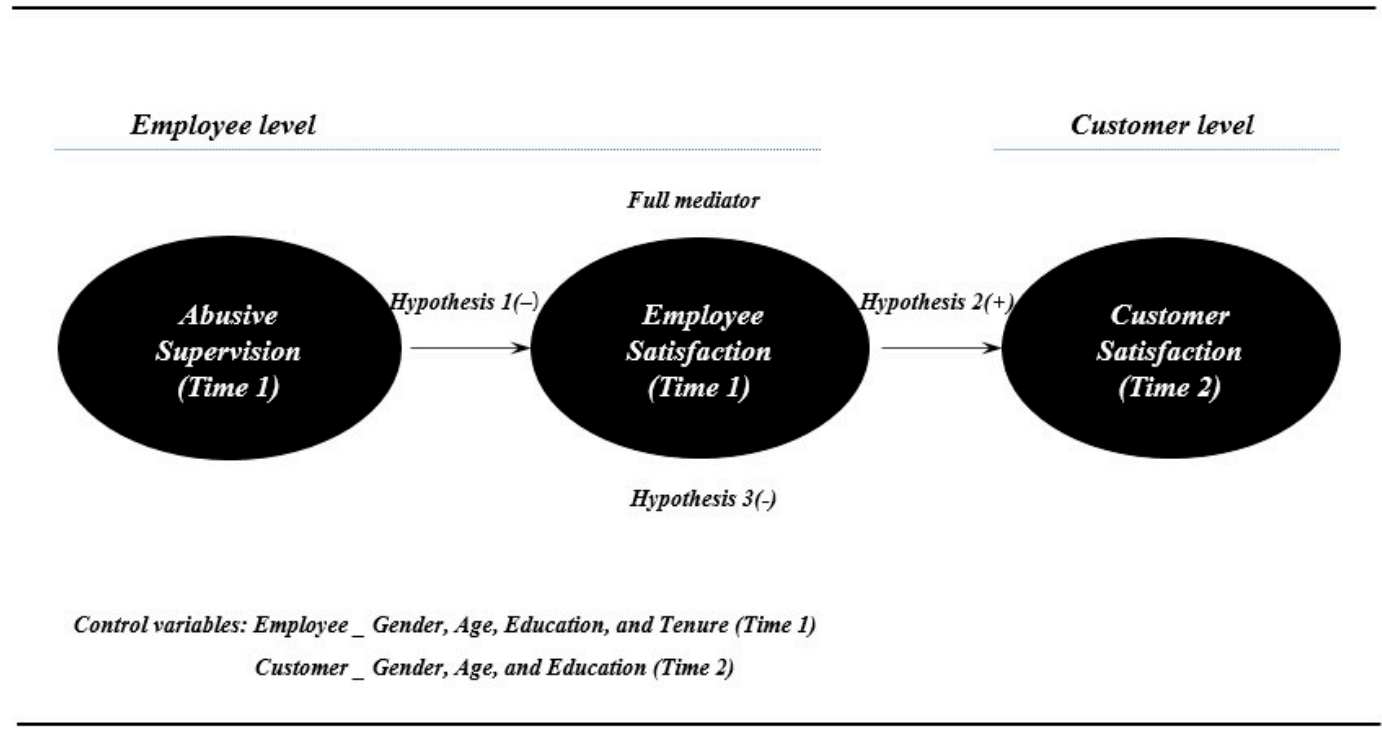

Figure 1. Research model.

\section{Theoretical Background and Hypothesis Development}

\subsection{Relationship between Abusive Supervision and Employee Satisfaction}

Tepper [5] explained that abusive supervision is a subordinate employee's perception of the supervisor in relation to the extent of the display of hostile verbal and nonverbal behaviors that do not include physical contact. Most studies on abusive supervisors have shown that an abusive supervisor's behaviors-expressed in the form of destructive leadership-did not result in constructive employee behavior [17,18]. Work satisfaction is a principal topic of research in the workplace [19]; it indicates development of favorable emotion toward one's work, based on evaluation of work experience [20]. The more abusive the supervisor, the weaker the acknowledgment of distributive justice and the lower the level of work satisfaction [21]. Similarly, Lin, Wang and Chen [22] argued that an abusive supervisor hurts the employees' well-being, especially through poorer mental health and lower work satisfaction. Ahmad, Khattak, and Ahmad [23] also asserted that employees experience unwanted emotions and responses due to an abusive supervisor's behaviors, and thus grow dissatisfied with work. Kernan et al. [24] maintained that a supervisor's abusive behaviors make their subordinates feel insulted, thereby negatively affecting their work satisfaction. Mathieu and Babiak [25] argued that swearing and other nonverbal abusive behaviors displayed to subordinates have an absolute influence on reducing work satisfaction, while Qian, Song, and Wang [26] found that a supervisor's insulting words and behaviors are closely tied to their subordinates' work dissatisfaction. Peltokorpi and Ramaswami [27] observed that abusive supervision affects subordinates' work satisfaction negatively, caused by the employees' negative response to why they are mistreated. In summary, higher abusive supervision leads to lower job satisfaction, while lower abusive supervision leads to higher job satisfaction. Given these findings, the following hypothesis was proposed:

Hypothesis 1 (H1). Abusive supervision is negatively related to employee satisfaction. 


\subsection{Relationship between Employee Satisfaction and Customer Satisfaction}

Locke [28] defined employee satisfaction as a pleasant emotional state that can help to achieve work value for the employee or facilitate such achievement. Gundersen, Heide, and Olsson [29] defined customer satisfaction as postpurchase evaluation of the product or service. Many studies have shown a highly positive relationship between work satisfaction and customer satisfaction. Research has shown that satisfied employees can give greater satisfaction to customers [30,31]. Similarly, Spinelli and Canavos [32] found a tight correlation between employee satisfaction and customer satisfaction and that a customer reacts highly favorably to nimble and competent workers who are satisfied with their work. Moreover, employees who are satisfied with their work can elicit loyal customer behaviors [33]. Employee satisfaction is a core issue of interest in the service industry [34]. There is a very strong positive correlation between employee satisfaction and customer satisfaction. Customer satisfaction is particularly important in the service industry [11]: the more satisfied the employees, the easier it is to retain customers, leading to the greater financial performance of the company thanks to positive word of mouth from satisfied customers. Jeon and Choi [35] argued that employee satisfaction affects customer satisfaction positively, but not the other way around, and thus the two have a unidirectional relationship. Overall, the literature suggests that employee satisfaction is an important antecedent for improving customer satisfaction [36-41]. In view of the existing empirical evidence, the following hypothesis was formulated:

Hypothesis 2 (H2). Employee satisfaction is positively related to customer satisfaction.

In consideration of hypotheses 1 and 2, it can be surmised that employees' perception of abusive supervision would possibly affect customer satisfaction through the mediation of employee satisfaction. Lyu, Zhou, Li, Wan, Zhang, and Qiu [42] argued that abusive supervision lowers employees' satisfaction, which in turn negatively affects employees' customer-oriented service behavior. Given this, it would certainly reduce customer satisfaction. Accordingly, the following hypothesis was proposed:

Hypothesis 3 (H3). Employee satisfaction mediates the relationship between abusive supervision and customer satisfaction.

\section{Research Methodology}

\subsection{Samples and Procedures}

We prepared two surveys to test these three hypotheses while reducing common method bias (CMB) error. One survey measured employees' perception of abusive supervision and their work satisfaction, and the other measured customer satisfaction. For the survey, we obtained consent from the managers of five family chain restaurants in Seoul, Republic of Korea-the top five of 2018-and handed out the survey to 10 servers at each restaurant. We assumed that three people, on average, sit at one table, and accordingly, for two stores of one family restaurant chain, we distributed 20 copies of the employee survey and 60 copies of the customer survey. For Time 1, employees replied with their perception of abusive supervision and their level of work satisfaction; for Time 2, customers reported their level of satisfaction with the same employees' service. The servers were asked to select customers who would participate in the survey. In cooperation with the restaurant managers, we conducted a survey for customers during their wait for dessert. To facilitate the process, complimentary drinks were provided to the customers, and we offered a small fee to the participating restaurants. Out of 100 employee surveys, 93 legitimate replies were returned (a 93.0\% return rate). To measure customer satisfaction with the servers' service quality, the same server's customers were asked to take the survey, matching the two sets of surveys. Unmatched replies were omitted, and the final sample of customers 
totaled 228, an average of 2.45 customers for each server. Subsequently, we tested the hypotheses with the sample data from 93 employees and 228 customers.

\subsection{Instrument Development}

The study measures were grouped into four categories: demographic characteristics, abusive supervision, employee satisfaction, and customer satisfaction. The original survey questions in English were translated to Korean, according to Brislin [43], and Paramewaran and Yaprak [44].

Part one of the questionnaire contained the demographic characteristics of employees and customers (e.g., age, gender, and education). The survey instrument that measured abusive supervision, employee satisfaction, and customer satisfaction used a 7-point Likert scale: "How much do you agree or disagree with these statements?" (1: strongly disagree, to 7: strongly agree). To measure employees' perception of abusive supervision, the present study adopted 15 items from the scales created by Tepper [5] and Lyu et al. [42]. Sample items included: "My supervisor ... expresses anger toward me when he/she is mad for another reason," " ... puts me down in front of others," and "... is rude to me." To measure employees' satisfaction, this study adapted the scales of Spector [45], Netemeyer, Boles, McKee, and McMurrian [46], and Yang [47] and examined five items, which included: "In general I am satisfied with my job", "I like doing the things I do at work", and "I sometimes feel my job is meaningful." Customer satisfaction was measured by five items based on Bitner and Hubbert [48], Fornell, Johnson, Anderson, Cha, and Bryant [49], and Fishbein and Ajzen [50]. These items included: "I really enjoyed myself at the restaurant", "I am pleased to visit this restaurant", and "Overall, I am satisfied with my experience at this restaurant."

\subsection{Data Analysis}

Descriptive statistics and frequency analysis were performed to make a profile of the samples using SPSS 16.0. Following the two-step approach recommended by Anderson and Gerbing [51], a confirmatory factor analysis (CFA) with maximum likelihood was measured to estimate the measurement model. Finally, structural equation modeling (SEM), using AMOS 5.0 (the maximum likelihood method), was conducted to test the research hypotheses.

\section{Results}

\subsection{Sample Profile}

The sample profiles are shown in Table 1 . The employees' $(\mathrm{N}=93)$ demographic characteristics were as follows. Half of the respondent employees (51.7\%) were in the age group 30-39, and there were more females $(74.2 \%)$ than males $(25.8 \%)$. More than half $(60.3 \%)$ had at least a university degree. Customers' $(\mathrm{N}=228)$ demographic characteristics were as follows: $41.6 \%$ were 20 to 29 years of age, and slightly over half of the respondents (57.5\%) were female. Most customers $(68.4 \%)$ had a university degree.

\subsection{Measurement Model}

As shown in Table 2, the measurement model indicated a good fit $\left(\chi^{2}=995.87, \mathrm{df}=272, \chi^{2} / \mathrm{df}=3.66\right.$; goodness of fit index $(\mathrm{GFI})=0.80$; normed fit index $(\mathrm{NFI})=0.88$; comparative fit index $(\mathrm{CFI})=0.91$; root square error of approximation $($ RMSEA $)=0.09$ ). All standardized factor loadings exceeded 0.70 , and each indicator's $t$-value exceeded $10.0(p<0.001)$ [51]. Composite reliabilities $(0.92$ to 0.96$)$ and Cronbach's alpha (0.93 to 0.98$)$ indicated internal consistency of the construct. In addition, the average variance extracted (AVE) value was greater than the squared values of the coefficients (Table 3). Average shared variance and maximum shared variance were smaller than the AVE value; thereby, the discriminant validity of the model was verified (Table 3) [52,53]. A review of the correlation between the measured items showed that employee satisfaction and customer satisfaction had a 
negative correlation with abusive supervision. The direction of the correlation therefore complied with the hypotheses.

Table 1. Profile of the sample.

\begin{tabular}{ccccc}
\hline & Employee $\mathbf{( N = 9 3 )}$ & \multicolumn{2}{c}{ Customer $\mathbf{( N = 2 2 8 )}$} \\
\hline Characteristic & N Percentage & N & Percentage \\
\hline Age & & & & \\
20 to 29 years & 45 & 48.3 & 95 & 41.6 \\
30 to 39 years & 48 & 51.7 & 80 & 35.2 \\
Older than 40 years & - & - & 53 & 23.2 \\
\hline Gender & & & 97 & 42.5 \\
Male & 24 & 25.8 & 131 & 57.5 \\
Female & 69 & 74.2 & & \\
Education & & & 27 & 68.4 \\
Community college degree (2 years) & 34 & 36.5 & 156 & 19.8 \\
University degree (4 years) & 56 & 60.3 & 45 & \\
Graduate degree (2 years) & 3 & 3.2 & & \\
\hline
\end{tabular}

Table 2. Reliabilities and confirmatory factor analysis properties.

\begin{tabular}{|c|c|c|c|c|}
\hline Construct & $\begin{array}{l}\text { Standardized } \\
\text { Loadings }\end{array}$ & $t$-Value & $\begin{array}{l}\text { Composite } \\
\text { Reliabilities }\end{array}$ & $\begin{array}{c}\text { Cronbach's } \\
\text { Alpha }\end{array}$ \\
\hline Abusive supervision & & & 0.96 & 0.98 \\
\hline $\mathrm{AS}_{1}$ & 0.88 & fixed & & \\
\hline $\mathrm{AS}_{2}$ & 0.83 & $18.61^{* * *}$ & & \\
\hline $\mathrm{AS}_{3}$ & 0.85 & $19.62 * * *$ & & \\
\hline $\mathrm{AS}_{4}$ & 0.91 & $22.74^{* * *}$ & & \\
\hline $\mathrm{AS}_{5}$ & 0.92 & $23.82^{* * *}$ & & \\
\hline $\mathrm{AS}_{6}$ & 0.91 & $23.19^{* * *}$ & & \\
\hline $\mathrm{AS}_{7}$ & 0.87 & $20.78^{* * *}$ & & \\
\hline $\mathrm{AS}_{8}$ & 0.83 & $18.96^{* * *}$ & & \\
\hline $\mathrm{AS}_{9}$ & 0.87 & $20.76^{* * *}$ & & \\
\hline $\mathrm{AS}_{10}$ & 0.85 & $19.57^{* * *}$ & & \\
\hline $\mathrm{AS}_{11}$ & 0.89 & $21.63^{* * *}$ & & \\
\hline $\mathrm{AS}_{12}$ & 0.88 & $21.06^{* * *}$ & & \\
\hline $\mathrm{AS}_{13}$ & 0.89 & $22.03^{* * *}$ & & \\
\hline $\mathrm{AS}_{14}$ & 0.90 & $22.58^{* * *}$ & & \\
\hline $\mathrm{AS}_{15}$ & 0.89 & $21.82^{* * *}$ & & \\
\hline Employee satisfaction & & & 0.92 & 0.93 \\
\hline $\mathrm{ES}_{1}$ & 0.84 & fixed & & \\
\hline $\mathrm{ES}_{2}$ & 0.82 & $16.42^{* * *}$ & & \\
\hline $\mathrm{ES}_{3}$ & 0.90 & $19.01^{* * *}$ & & \\
\hline $\mathrm{ES}_{4}$ & 0.86 & $17.70^{* * *}$ & & \\
\hline $\mathrm{ES}_{5}$ & 0.86 & $17.78^{* * *}$ & & \\
\hline Customer satisfaction & & & 0.93 & 0.93 \\
\hline $\mathrm{CS}_{1}$ & 0.94 & fixed & & \\
\hline $\mathrm{CS}_{2}$ & 0.82 & 19.91 & & \\
\hline $\mathrm{CS}_{3}$ & 0.74 & 15.65 & & \\
\hline $\mathrm{CS}_{4}$ & 0.94 & 29.84 & & \\
\hline $\mathrm{CS}_{5}$ & 0.76 & 16.66 & & \\
\hline
\end{tabular}

Note: $\chi^{2}=995.87, \mathrm{df}=272, \chi^{2} / \mathrm{df}=3.66$, goodness of fit index $(\mathrm{GFI})=0.80$, normed fit index $(\mathrm{NFI})=0.88$, comparative fit index $(\mathrm{CFI})=0.91$, root mean square error of approximation $($ RMSEA $)=0.07 ; * * * p<0.001 \mathrm{~g}$. 
Table 3. Correlations among the latent constructs.

\begin{tabular}{|c|c|c|c|c|c|c|c|}
\hline \multirow[t]{2}{*}{ Construct } & \multicolumn{6}{|c|}{ Discriminant Validity } & \multirow{2}{*}{$\begin{array}{c}\begin{array}{c}\text { Descriptive } \\
\text { Statistics }\end{array} \\
\mathrm{M} \pm \mathrm{SD}\end{array}$} \\
\hline & 1 & 2 & 3 & AVE & ASV & MSV & \\
\hline 1. Abusive supervision & 1 & 0.13 & 0.08 & 0.71 & 0.11 & 0.14 & $3.24 \pm 1.09$ \\
\hline 2. Employee satisfaction & -0.36 & 1 & 0.24 & 0.73 & 0.21 & 0.25 & $3.97 \pm 0.96$ \\
\hline 3. Customer satisfaction & -0.29 & 0.49 & 1 & 0.71 & 0.16 & 0.25 & $4.05 \pm 0.84$ \\
\hline
\end{tabular}

\subsection{Structural Equation Modeling}

The structural equation model fit was good $\left(\chi^{2}=998.28 ; \mathrm{GFI}=0.74 ; \mathrm{NFI}=0.87 ; \mathrm{CFI}=0.91\right.$; RMSEA $=0.09$ ). Table 4 presents the estimated model, illustrating the direction and magnitude of the impact of the standardized path coefficients. The employees' perception of abusive supervision negatively predicted employee satisfaction $(\beta=-0.38 ; t=-6.12 ; p<0.001)$, supporting Hypothesis 1 . Employee satisfaction $(\beta=0.51 ; t$-Value $=8.25 ; p<0.001)$ had a significant effect on customer satisfaction; Hypothesis 2 was therefore supported.

Table 4. Structural parameter estimates.

\begin{tabular}{cccc}
\hline $\begin{array}{c}\text { Hypothesized Path } \\
\text { (Stated as Alternative Hypothesis) }\end{array}$ & $\begin{array}{c}\text { Standardized } \\
\text { Path Coefficients }\end{array}$ & $\boldsymbol{t}$-Value & Results \\
\hline H1: Abusive supervision & -0.38 & $-6.12 * * *$ & Supported \\
$\rightarrow$ Employee satisfaction & +0.51 & $+8.25 * * *$ & Supported \\
H2: Employee satisfaction & & $\chi^{2}=998.28(p<0.001)$ & \\
$\rightarrow$ Customer satisfaction & $\mathrm{df}=273$ & \\
Goodness of fit statistics & $\chi^{2} / \mathrm{df}=3.65$ & \\
& $\mathrm{GFI}=0.74$ & \\
$\mathrm{NFI}=0.87$ & $\mathrm{CFI}=0.91$ \\
$\mathrm{RMSEA}=0.07$ & $\mathrm{RMR}=0.09$ \\
\hline
\end{tabular}

Note: ${ }^{* * *} p<0.001$; GFI = Goodness of Fit Index; NFI = Normed Fit Index; CFI = Comparative Fit Index; RMSEA $=$ Root Mean Square Error of Approximation, RMR = Root Mean Square Residual.

Table 5 shows the mediating effect of employee satisfaction on how employees' perception of abusive supervision affected customer satisfaction (Hypothesis 3). Four conditions of Baron and Kenny [54] — a significant relationship among the independent, dependent, and mediating variables-were confirmed, as shown in Tables 3 and 4. According to the analysis, the direct impact of abusive supervision on customer satisfaction was not significant in the mediating model $(\beta=-0.09$; $t=-1.55 ; p>0.05)$, but it turned out significant in the restricted model $(\beta=-0.27 ; t=-4.43$; $p<0.001)$, as did the difference in $\chi^{2}(\Delta \times 2(\Delta \mathrm{df}=1)=50.92 ; p<0.05)$ between the restricted model $\left(\chi^{2}(\mathrm{df}=273)=1046.79\right)$ and the mediating model $\left(\chi^{2}(\mathrm{df}=272)=995.87\right)$. These findings confirm that employees' perceptions of abusive supervision negatively affect customer satisfaction through full mediation of employee satisfaction. Hypothesis 3 is therefore also accepted. 
Table 5. Mediating test (full mediator).

\begin{tabular}{lcccc}
\hline & \multicolumn{2}{c}{$\begin{array}{c}\text { Constrained Model } \\
(\mathbf{E S} \rightarrow \mathbf{C S}=\mathbf{0})\end{array}$} & \multicolumn{2}{c}{ Mediating Model } \\
\hline & $\boldsymbol{\beta}$ & $\boldsymbol{t}$-Value & $\boldsymbol{\beta}$ & $\boldsymbol{t}$-Value \\
\hline H3: Abusive supervision & -0.27 & $-4.43^{* * *}$ & -0.09 & $-1.55^{\mathrm{ns}}$ \\
$\rightarrow$ Customer satisfaction & $\chi^{2}(\mathrm{df}=273)$ & 1046.79 & $\chi^{2}(\mathrm{df}=272)$ & 995.87 \\
\hline & \multicolumn{4}{c}{$\Delta \chi^{2}(\mathrm{df}=1)=50.92 *$} \\
\hline
\end{tabular}

Note: ${ }^{* * *} p<0.001, * p<0.05 ; \mathrm{ES}=$ employee satisfaction, $\mathrm{CS}=$ customer satisfaction, $\mathrm{ns}=$ not significant.

\section{Discussion and Implications}

\subsection{Discussion of Results}

The objective of this study was to figure out the interrelationship of abusive supervision, employee satisfaction and customer satisfaction at chain restaurants. According to the analysis results, abusive supervision negatively affected employee satisfaction, supporting previous studies on abusive supervision and employee satisfaction [25,26] A positive causal relationship was observed between employee satisfaction and customer satisfaction [11,35], suggesting that abusive supervision reduces employee satisfaction, which in turn lowers customer satisfaction significantly. This study verified the secondhand influence of employee satisfaction, by showing that abusive supervision negatively affects customer satisfaction through the mediation of employee satisfaction. In other words, with abusive supervision, employees grow dissatisfied with their workplace and work, fail to provide satisfying service to customers, and thus negatively affect customer satisfaction.

\subsection{Theoretical and Practical Implications}

This study makes several theoretical and practical contributions. It provides useful data to understand the organic relationship between abusive supervision, employee satisfaction, and customer satisfaction. Previous studies mostly examined employees' psychological responses or attitudes toward perceived abusive supervision. However, this study set customer satisfaction as the final dependent variable and took an exploratory approach, with a focus on the relationship between abusive supervision, employee satisfaction, and customer satisfaction. As the first of its kind, this study is expected to provide useful information about related issues. We found that customer satisfaction is not directly reduced by abusive supervision, but rather through the mediatory role of employee satisfaction. Another academic contribution is that paired-surveys were conducted by matching chain restaurant servers and customers to minimize CMB error.

One of the practical contributions of this study is that it highlights that employees' work dissatisfaction can be quite costly at an organizational level, given the significant ripple effect of the negative influence of abusive supervision. When employees feel that they are abused by their supervisor, their work satisfaction falters, which eventually affects the service they provide to customers, resulting in reduced customer satisfaction. Since abusive supervision affects both employee satisfaction and customer satisfaction, all-out efforts are needed at an organizational level to deter abusive supervision. Specifically, it is necessary to manage a systematic supervisory program and encourage internal whistle-blowing to prevent abusive supervision, considering that employees who work with abusive and insulting supervisors tend to replicate such behaviors, even in worse forms [55]. It might also be advisable to conduct continued training and education at an organizational level, develop a program and provide coaching to improve supervisor-employee relationships, and support leisure activities. Supervisors need to learn management skills to properly treat and interact with employees, and these need to be continuously monitored to prevent abusive supervision. Additionally, leadership training needs to be conducted to foster ideal leadership for supervisors and enable efficient communication 
with employees. As a result, it was suggested that systematic management of abusive supervision at the organizational level is essential to improve organizational performance.

\subsection{Limitations and Future Research}

Despite these benefits, this study poses several limitations. First, the research sample consisted of chain restaurant servers and customers as a subcategory of the foodservice industry. Thus, the outcomes may be only applicable to a particular customer segment. There may also be variable errors due to the use of convenience sampling. In future research, comparative analysis needs to be conducted with an expanded sample from other companies within the foodservice industry. Second, it was observed that abusive supervision indirectly affected customer satisfaction through the mediation of employee satisfaction. More research needs to be undertaken to test a direct effect of abusive supervision on customer satisfaction.

Author Contributions: The authors contributed equally to this work. All the authors contributed to the conceptualization, formal analysis, investigation, methodology, writing of the original draft, and review and editing. All authors have read and agreed to the published version of the manuscript.

Funding: This research received no external funding.

Conflicts of Interest: The authors declare no conflict of interest.

\section{References}

1. Zellars, K.L.; Tepper, B.J.; Duffy, M.K. Abusive supervision and subordinates' organizational citizenship behavior. J. Appl. Psychol. 2002, 87, 1068-1076. [CrossRef]

2. Aasland, M.; Skogstad, A.; Notelaers, G.; Nielsen, M.; Einarsen, S. The prevalence of destructive leadership behaviour. Br. J. Manag. 2010, 21, 438-452. [CrossRef]

3. Schyns, B.; Schilling, J. How bad are the effects of bad leaders? A meta-analysis of destructive leadership and its outcomes. Leadersh. Q. 2013, 24, 138-158. [CrossRef]

4. Tepper, B.J;; Simon, L.; Park, H.M. Abusive supervision. Annu. Rev. Organ. Psychol. Organ. Behav. 2017, 4, 123-152. [CrossRef]

5. Tepper, B.J. Consequences of abusive supervision. Acad. Manag. J. 2000, 43, 178-190.

6. Harris, K.J.; Lambert, A.; Harris, R.B. HRM effectiveness as a moderator of the relationship between abusive supervision and technology work overload and job outcomes for technology end users. J. Appl. Soc. Psychol. 2013, 43, 1686-1695. [CrossRef]

7. Burton, J.P.; Hoobler, J.M.; Scheuer, M.L. Supervisor workplace stress and abusive supervision: The buffering effect of exercise. J. Bus. Psychol. 2012, 27, 271-279. [CrossRef]

8. Inness, M.; Barling, J.; Turner, N. Understanding supervisor-targeted aggression: A within-person, between-jobs design. J. Appl. Psychol. 2005, 90, 731-739. [CrossRef]

9. Amundsen, S.; Martinsen, O.L. Self-other agreement in empowering leadership: Relationships with leader effectiveness and subordinates' job satisfaction and turnover intention. Leadersh. Q. 2014, 25, 784-800. [CrossRef]

10. Arenas, A.; Giorgi, G.; Montani, F.; Mancuso, S.; Perez, J.F.; Mucci, N. Workplace bullying in a sample of Italian and Spanish employees and its relationship with job satisfaction, and psychological well-being. Front. Psychol. 2016, 6, 1912. [CrossRef]

11. Chi, C.G.; Gursoy, D. Employee satisfaction, customer satisfaction, and financial performance: An empirical examination. Int. J. Hosp. Manag. 2009, 28, 245-253. [CrossRef]

12. Jung, H.S.; Yoon, H.H. Do employees' satisfied customers respond with a satisfactory relationship? The effects of employees' satisfaction on customers' satisfaction and loyalty in a family restaurant. Int. J. Hosp. Manag. 2013, 34, 1-8. [CrossRef]

13. Wangenheim, F.V.; Evanschitzky, H.; Wunderlich, M. Does the employee-customer satisfaction link hold for all employee groups? J. Bus. Res. 2007, 60, 690-697. [CrossRef]

14. Mackey, J.D.; Frieder, R.E.; Brees, J.R.; Martinko, M.J. Abusive supervision: A meta-analysis and empirical review. J. Manag. 2017, 43, 1940-1965. [CrossRef] 
15. Schyns, B.; Felfe, J.; Schilling, J. Is it me or you? How reactions to abusive supervision are shaped by leader behavior and follower perceptions. Front. Psychol. 2018, 9, 1309. [CrossRef]

16. Park, H.; Hoobler, J.M.; Wu, J.; Liden, R.C.; Hu, J.; Wilson, M.S. Abusive supervision and employee deviance: A multifoci justice perspective. J. Bus. Ethics 2019, 158, 1113-1131. [CrossRef]

17. Bowling, N.A.; Michel, J.S. Why do you treat me badly? The role of attributions regarding the cause of abuse in subordinates' response to abusive supervision. Work Stress. 2011, 25, 309-320. [CrossRef]

18. Pan, W.; Sun, L.; Sun, L.Y.; Li, C.; Leung, A.S.M. Abusive supervision and job-oriented constructive deviance in the hotel industry: Test of nonlinear mediation and moderated curvilinear model. Int. J. Contemp. Hosp. Manag. 2018, 30, 2249-2267. [CrossRef]

19. Velez, M.J.; Neves, P. The relationship between abusive supervision, distributive justice and job satisfaction: A substitutes for leadership approach. Eur. Rev. Appl. Psychol. 2017, 67, 187-198. [CrossRef]

20. Cranny, C.J.; Smith, P.C.; Stone, E.F. Job Satisfaction: How People Feel about Their Jobs and How it Affects Their Performance; Lexington Book: Lanham, MD, USA, 1992.

21. Tepper, B.; Duffy, M.; Shaw, J. Personality moderators of the relationship between abusive supervision and subordinates' resistance. J. Appl. Psychol. 2001, 86, 974-983. [CrossRef]

22. Lin, W.; Wang, L.; Chen, S. Abusive supervision and employee well-being: The moderating effect of power distance orientation. Appl. Psychol. Int. Rev. 2013, 62, 308-329. [CrossRef]

23. Ahmad, W.; Khattak, A.J.; Ahmad, G. Impact of abusive supervision on job satisfaction and turnover intention: Role of power distance as a moderator. City Univ. Res. J. 2016, 6, 122-136.

24. Kernan, M.C.; Racicot, B.M.; Fisher, A.M. Effects of abusive supervision, psychological climate, and felt violation on work outcomes: A moderated mediated model. J. Leadersh. Organ. Stud. 2016, 23, 309-321. [CrossRef]

25. Mathieu, C.; Babiak, P. Corporate psychopathy and abusive supervision: Their influence on employees' job satisfaction and turnover intentions. Personal. Individ. Differ. 2016, 91, 102-106. [CrossRef]

26. Qian, J.; Song, B.; Wang, B. Abusive supervision and job dissatisfaction: The moderating effects of feedback avoidance and critical thinking. Front. Psychol. 2017, 8, 496. [CrossRef]

27. Peltokorpi, V.; Ramaswami, A. Abusive supervision and subordinates' physical and mental health: The effects of job satisfaction and power distance orientation. Int. J. Hum. Resour. Manag. 2019, 1-27. [CrossRef]

28. Locke, E.A. What is job satisfaction. Organ. Behav. Hum. Perform. 1969, 4, 309-336. [CrossRef]

29. Gundersen, M.G.; Heide, M.; Olsson, U.H. Hotel Guest satisfaction among Business Travellers: What Are the Important Factors? Cornell Q. 1996, 37, 72-81.

30. Loveman, G.W. Employee satisfaction, customer loyalty and financial performance: An empirical examination of the service profit chain in retail banking. J. Ser. Res. 1998, 1, 18-31. [CrossRef]

31. Randy, B. Why loyal employees and customers improve the bottom line. J. Qual. Particip. 2000, 23, 40-44.

32. Spinelli, M.A.; Canavos, G.C. Investigating the relationship between employee satisfaction and guest satisfaction. Cornell Q. 2000, 41, 29-33. [CrossRef]

33. Allen, N.J.; Grisaffe, D.B. Employee commitment to the organization and customer reactions: Mapping the linkages. Hum. Res. Manag. Rev. 2001, 11, 209-236. [CrossRef]

34. Matzler, K.; Renzl, B. Assessing asymmetric effects in the formation of employee satisfaction. Tour. Manag. 2007, 28, 1093-1103. [CrossRef]

35. Jeon, H.; Choi, B. The relationship between employee satisfaction and customer satisfaction. J. Ser. Mark. 2012, 26, 332-341. [CrossRef]

36. Keiningham, T.L.; Aksoy, L.; Cooil, B.; Peterson, K.; Vavra, T.G. A longitudinal examination of the asymmetric impact of employee and customer satisfaction on retail sales. Manag. Ser. Q. Int. J. 2006, 16, 442-459. [CrossRef]

37. Gil, I.; Berenguer, G.; Cervera, A. The roles of service encounters, service value, and job satisfaction in achieving customer satisfaction in business relationship. Indust. Mark. Manag. 2008, 37, 921-939. [CrossRef]

38. Amoopour, M.; Hemmatpour, M.; Mirtaslimi, S.S. Job satisfaction of employee and customer satisfaction. Arab. J. Bus. Manag. Rev. 2014, 3, 1-6. [CrossRef]

39. Shaheen, I.; Naseem, N. A review of customer satisfaction, employee satisfaction and their impact on firm performance. Int. J. Manag. Organ. Stud. 2015, 4, 21-31.

40. Evanschitzky, H.; Groening, C.; Mittal, V.; Wunderlich, M. How employer and employee satisfaction affect customer satisfaction: An application to franchise services. J. Ser. Res. 2011, 14, 136-148. [CrossRef] 
41. Wolter, J.S.; Bock, D.; Mackey, J.; Xu, P.; Smith, J.S. Employee satisfaction trajectories and their effect on customer satisfaction and repatronage intentions. J. Acad. Mark. Sci. 2019, 47, 815-836. [CrossRef]

42. Lyu, Y.; Zhou, X.; Li, W.; Wan, J.; Zhang, J.; Qiu, C. The impact of abusive supervision on service employees' proactive customer service performance in the hotel industry. Int. J. Contemp. Hosp. Manag. 2016, 28, 1992-2012. [CrossRef]

43. Brislin, R.W. Translation and content analysis of oral and written material. In Handbook of Cross-Cultural Psychology: Methodology; Triandis, H.C., Berry, J.W., Eds.; Allyn and Bacon: Boston, MA, USA, 1980; pp. 389-444.

44. Paramewaran, R.; Yaprak, A. A Cross-National Comparison of Consumer Research Measures. J. Int. Bus. Stud. 1987, 18, 35-49. [CrossRef]

45. Spector, P.E. Measurement of human service staff satisfaction: Development of the job satisfaction survey. Am. J. Comm. Psychol. 1985, 13, 693-713. [CrossRef] [PubMed]

46. Netemeyer, R.G.; Boles, J.S.; McKee, D.O.; McMurrian, R. An investigation into the antecedents of organizational citizenship behaviors in a personal selling context. J. Mark. 1997, 61, 85-98. [CrossRef]

47. Yang, J.T. Antecedents and consequences of job satisfaction in the hotel industry. Int. J. Hosp. Manag. 2010, 29, 609-619. [CrossRef]

48. Bitner, M.J.; Hubbert, A.R. Encounter satisfaction versus overall satisfaction versus service quality: The consumer's voice. In Service Quality: New Directions in Theory and Practice; Rust, R.T., Oliver, R.L., Eds.; Sage Publications: Sauzenda Oakes, CA, USA, 1994.

49. Fornell, C.; Johnson, M.D.; Anderson, E.W.; Cha, J.; Bryant, E.B. The American customer satisfaction index: Nature, purpose, and findings. J. Mark. 1996, 60, 7-18. [CrossRef]

50. Fishbein, M.; Ajzen, I. Belief, Attitude, Intention and Behaviour an Introduction to Theory and Research; Addison-Wesley Publishing Co, Inc.: Boston, MA, USA, 1975.

51. Anderson, J.C.; Gerbing, D.W. Structural equation modeling in practice: A review and recommended 540 two-step approach. Psychol. Bull. 1988, 103, 411-423. [CrossRef]

52. Bentler, P.M.; Bonett, D.G. Significance tests and goodness of fit in the analysis of covariance structures. Psychol. Bull. 1980, 88, 588-606. [CrossRef]

53. Hair, J.; Black, W.C.; Babin, B.J.; Anderson, R.E. Multivariate Data Analysis, 7th ed.; Prentice Hall: Upper Saddle River, NJ, USA, 2010.

54. Baron, R.M.; Kenny, D.A. The moderator-mediator variable distinction in social psychological research: Conceptual, strategic, and statistical considerations. J. Personal. Soc. Psychol. 1986, 51, 1173-1182. [CrossRef]

55. Mackey, J.D.; Brees, J.R.; McAllister, C.P.; Zorn, M.L.; Martinko, M.J.; Harvey, P. Victim and culprit? The effects of entitlement and felt accountability on perceptions of abusive supervision and perpetration of workplace bullying. J. Bus. Ethics 2016, 138, 659-673. [CrossRef] 